\title{
Awareness and Practice of Cervical Cancer Screening and Human Papilloma Virus Vaccination (HPV) Uptake among Female Staff in Private Tertiary Hospital in Lagos Nigeria
}

\author{
Article by Aisagbonhi Henry Osaro ${ }^{1}$, Mgbeafuluba Ifeyinwa Constance ${ }^{2}$ \\ ${ }^{1}$ MPH, Texila American University, Olabisi Onabanjo University Teaching Hospital \\ ${ }^{2}$ Eko Hospitals Plc \\ E-mail: henroid100@hotmail.com ${ }^{1}$
}

\begin{abstract}
Cancer burden in Nigeria has become a sudden nightmare which is fast having a disastrous impact on the health and financial economy. The estimated number of new cancer cases in West Africa is 854,790. In Nigeria, about $8.5 \%$ of the 51million annual death due to cancer account for cervical cancer. In this cross sectional descriptive study amongst female Private health workers, a significant level of awareness of cervical cancer amongst the female health workers in the private health sector was observed. The level of awareness is strongly associated with enhanced education but there was no link with age or marital status. A significant link between the level of awareness and health occupation especially the core health workers were also observed. However, there was a marginal link with the non-medical health workers. Furthermore, there was a significant link illustrating that a possible increased participation in cancer awareness programs would lead to; Increase in knowledge of CC status, increase in utilization of Pap smear test and improved uptake of HPV vaccine. This outcome serves as an original article data base to resolve any doubt and perception on the level of knowledge and awareness of Cervical Cancer amongst private sector health workers in Lagos state and extendable to Nigeria.
\end{abstract}

Keywords: Cervical Cancer - CC, Human Papilloma Virus- HPV, Vaccination uptake -VU, Papanicolaou (pap) smear test, Sexual transmitted diseases (STD).

\section{Introduction}

Cervical cancer remains a significant leading cause of cancer related deaths and an adverse public health challenge in the developing world despite the large prospects for prevention and screening processes for early detection. A comprehensive strategic cancer prevention and early detection program is being implemented, but if a dependable and effective public awareness impact is largely associated with the ability of the health work force in health institutions and organizations, then the update awareness and knowledge of the subject issue mustn't be in doubt. What then is the level of awareness and practice of cervical cancer screening of the private sector health work force in Nigeria following the increasingly presence of private health care practitioners and institutions compared to the public owned health institutions?

Cancer burden in Nigeria has become a sudden nightmare which is fast having a disastrous impact on the health and financial economy. Cancer is a disease where malignant cells grow out of control and invade, erode and destroy normal tissue. Malignant cells invade neighbouring tissues, enter blood levels and metastasize to the different sites (All about cancer, 2016; National cancer institute, 2016). It is a group of over a hundred different diseases of which each disease have their own set of risk factors (Adebamowo et al, 2000). Cervical cancer is an important women's reproductive health problem, especially in developing countries. Efforts towards its prevention worldwide have focused on screening women at risk of disease using pap smears and treating pre-cancerous lesions (Eke et al, 2010). Cervical cancer is a malignant disease of the cervix which has a pre-malignant stage which usually occurs in younger women under the age of forty years and in the 5 th or $6^{\text {th }}$ decade of life at a mean age of 54 years (Anorlu, 2006).

The risk of developing cancer increases with age it is associated with risk factors such as gender, race, personal and family medical history including long term use of oral contraceptive pills, early age 
at first sexual intercourse, early age at first birth multiparity, multiple unfaithful male sexual partners, smoking, immunosuppression and alcohol (Owoeye, 2013). Other risk factors, are largely related to lifestyle choices, while certain infections with human papilloma viruses (HPV) enhances exposure. Certain vitamin deficiencies and hormonal factors are also possible risk factors. Occupational exposures and some environmental factors can also be related to developing cancer.

National data describes cervical cancer as the third leading and most common cancer amongst women in developing countries (Cervical cancer prevention, 2016; Ayinde, 2003; WHO (2002)). Deaths from cancer in the world are projected to continue to rise, with an estimated nine million people to have died from cancer in 2015 and 11.4million by 2030 (WHO, 2007a; WHO. 2007b).

The estimated number of new cancer cases in West Africa is 854,790 (Global cancer facts and figure- 2016). In Nigeria, about $8.5 \%$ of the 51 million annual death due to cancer account for cervical cancer (Anorlu RJ, 2006) and the age standardized incidence of cervical cancer in 2008 was estimated to be 36.3 - 50.2 per 100,000 (GLOBOCAN, 2008), while the annual age-standardised incidence of cervical cancer in Africa has been projected to be 22,914 by 2025 (Parkin, et al 2003). In Bayelsa, a study reported an incidence of 1.5\% in 2011 (Oboma, 2013). Cervical cancer accounts for about 25\% of cancer deaths among black South African women (Cervical cancer Prevention, 2015) while In Zambia, a study shows 63 out of 100,000 women die from cervical cancer, same study showed 30.6\% crude incidence rate of cervical cancer in Zambia (Mwanahamintin, 2008; WHO, 2002). Cervical Cancer is still the second highest number of female cancer in Malaysia (Sherifa et al, 2008). In sub Saharan Africa, approximately 35 new cases of cervical cancer are diagnosed per 100, 000 women annually, and about 23 per 100000 women die from the disease (Bray et al, 2013), while about 80\% of the 466,000 new cases identified each New Year are in developing countries (Eke et al, 2008).

The WHO also predicted that approximately 5,007 new cases and 3,361 deaths of cervical cancer will occur by 2025 (Ziba, 2015).

If cancer awareness and care services are not expanded, it is estimated that by 2050 , the life time risk of cancer in Africa will increase by $50 \%$ to $60 \%$, doubling the annual number of cases to 2.2 million (Combating cancer in Africa, 2016).

Following various intervention and health impacts, research reports have recently shown that Cervical cancer deaths have decreased to an estimated 26\% between 1950 and 2013 due largely to the utilization of papanicolaou (pap) smear test for cervical cancer screening (Arevian et al, 2006). Therefore, $90 \%$ of women who have it can be cured if the cancer is found and treated early (Parham, 2004). Studies have also shown that cervical Cancer develop in 10years or more and therefore can be detected before cancer develops and cured completely. It is also a preventable disease (Arevian et al, 2006; Hakama et al, 1975).

However, the basic Knowledge about cervical cancer disease and symptoms are important in the effort to actualise early detection via screening and treatment. Studies have shown that knowledge of cancer patterns in Africa is woefully inadequate, and population-based epidemiological data on the occurrence of cancer in Sub-Saharan Africa especially, are sparse (Okonofua, 2007).

Life expectancy and prosperity have improved in both developed and developing countries over the past fifty years and are expected to keep running; however this was enabled by improvement on practise of periodic health check-up (Eke et al, 2010; Bjorn, 2002). Early detection through regular check-ups is an essentially a key aspect of the fight against cancer and other diseases. Experts in the field of oncology have suggested that cervical cancer can be eradicated through preventive screening via clinic visits or periodic health check-up and the early detection of precancerous and cancerous tritons. Cancer of the cervix has become less common in countries that use pap tests (Ferlay et al, 2004; Gharoro et al, 2006).

Cervical cancer has been linked with Human Papilloma Virus (HPV) which can be transmitted sexually and can be prevented just as any other sexually transmitted infection (STIs) (Bekkers, 2006). The proven effective means of combating cervical cancer morbidity and mortality is by engaging preventive measures. The most commonly used cervical screening method in Nigeria is the Pap test (cytology based pap and pap smear methods). Alternative screening approaches such as visual inspection with acetic acid (VIA), visual inspection with Lugol's iodine (VILI), cervicography and speculoscopy have also been explored in the prevention of cervical cancer in resource-poor settings 
(Balogun et al, 2012; Claeys et al, 2003). The Papanicolaou test in cervical cytological testing identifies cell abnormalities that may indicate or precede cervical cancer. It is ideal for sexually active young women and women of ages 30-40 years to engage in cervical screening exercise (Mityaba, 2016).

In most of the health care facilities, Human Papillomavirus (HPV) Vaccines are available, but despite the availability and acceptability of these services, most cervical cancer patient still present at late stages for treatment and this is largely due to low knowledge and awareness as reported in most researches including (Ayinde et al, 2004). Over 80\% of cancer infected women present with late stages. Studies attribute this too largely due to lack of awareness of the disease (Simaubi, 2013). It is therefore a high public health priority to increase the awareness and uptakes of HPV and cervical screening among the study population (Olowookere et al).

Since the greatest burden of cervical cancer occurs in the developing world where the mortality rate ranges from 10 to 35 per 100,000 compared with 2 to 4 deaths per 100,000 in developed nations (Arbyn, 2008), research showed that the difference was attributed to effective national screening programs of cervical cytological testing (the Papanicolaou test) to identify cell abnormalities that may indicate or precede cervical cancer (Peto et al, 2004; Quinn et al, 2003), as well as an effective public awareness impact championed by the health work force and health initiated organizations.

Globally, the overall burden of cancer of the breast and cervix is shifting substantially to vulnerable populations in ill prepared developing countries and in Nigeria, several subpopulations, such as rural women; remain relatively under screened (Akintoye, 2013).

These slum dwellers are disadvantaged in terms of their socio-economic status. They often have limited income, poor nutrition, and a low level of awareness about health issues, preventive behaviour and restricted access to health care services (Akintoye et al, 2013) offered mostly by the private health centres around the neighbourhood. Even in more developed countries, coverage levels for cervical cancer screening were found to be low among women of low socioeconomic status (Coughlin et al 2002; Behbakht, 2004).

Similarly, place of residence is important in predicting health outcomes. For example, according to a study by Barry et al, 2003, lower class and extreme poverty areas in the United States were more likely to have later stage diagnosis of cervical cancer.

Low levels of knowledge in cervical cancer across different literacy level in Africa have been reported (Ezem, 2007). Knowledge of cancer pattern in most studies is woefully inadequate and awareness level is also very poor (Okonofua, 2007). Low level of awareness and poor knowledge of cervical cancer screening services have resulted in limited number of women being screened in Nigeria. The few available public or private - secondary and tertiary health care facilities are located in few urban towns (Anorlu, 2008) and the conveyance of the awareness creation and knowledge involved is largely a responsibility of the health work force in the fore front of health care organizations and institutions. Although In Nigeria, a lot is been done in the training and retraining of the health workforce on cancer health issues, however the majority of the seminars and awareness programs are mostly targeted at or organized in the public owned tertiary institutions. Most commonly is that the attendances are largely the health work force from the public owned health institution with a minority from the private health sector whereas a majority of the health work force in the urban, rural subpopulations and other vulnerable populations are in the private health sector due to the increasingly presence of private health care practices and institutions compared to the public owned hospitals. Therefore if a dependable and effective public awareness impact is largely associated with the ability of the health work force in health institutions and organizations, the skills and update knowledge of the subject issue mustn't be in doubt. What then is the level of awareness, willingness, and practice of cervical cancer screening of the private sector health work force in Nigeria?

Although a comprehensive strategic cancer prevention and early detection program is being implemented but little success rate has been achieved (Ngoma, 2006; Anderson et al, 1988), however, this is important for Nigeria, which has $52 \%$ of the her 40.43 million women ages 15 years and older living in rural areas and at risk of developing cervical and breast cancers (Ajayi et al, 2013).The comprehensive strategic cancer prevention and early detection program will largely involve the private sector health care providers at the local grass root due to the rural structure distribution 
network. It is therefore crucial that health care work force must equip themselves with the basic knowledge and awareness skills. However, in a study at public owned health institution in Ibadan, Nigeria (Ayinde et al, 2003) aimed at finding out the level of awareness of female health workers about cervical cancer and the level of utilization of preventive measure found out that knowledge about the condition was high among doctors, inadequate among nurses and poor among hospitals maids. It was also observed that $93.2 \%$ of respondent have never had pap smears performed. It was reported that the poor utilisation of the cervical screening test was independent of respondent qualification, performance, marital status or hospital. Similar study in Ekiti Nigeria (Akintoye et al, 2013) showed a higher percentage of poor knowledge of cervical cancer and its prevention among young women. Only $1.4 \%$ had had Pap smear at least once.

In another research study, the uptake of cervical screening; awareness, willingness, and practice of cervical cancer screening was relatively high compared to other regional figures in Nigeria (Olowookere et al, 2012). In General, Cervical cancer screening is unacceptably low among respondents. It is therefore necessary to increase awareness of cervical screening and uptake of HPV among the study population (Olowookere et al, 2012).

Reports shows that the strongest barriers to screening in rural population include education, attitudes, religious beliefs, health care access (Ajayi et al, 2013) as well as the attitude of physicians to cancer screening and motivation by the community nurses (Arulogun et al, 2012).

Common to all the review papers during the literature review was that studies were done in public health institutions only both in Lagos state and other few states. There were no studies done in a private health care institution in Lagos Nigeria therefore the level of knowledge and awareness of Cervical Cancer screening among Nigerian female health workers within the reproductive ages in the private health sector is currently unknown and this may have direct impact on the success of cervical cancer screening programs.

The purpose of this study is to evaluate the association of the Awareness, Attitude and Practice of Cervical Cancer Screening and Human Papilloma Virus Vaccination Uptake among Female Staff in a Private Tertiary Hospital in Lagos Nigeria.

\section{Methods}

This study was conducted at the Eko Hospitals, Lagos. Lagos is a cosmopolitan city and the commercial nerve centre of Nigeria located in south western Nigeria in West Africa. Eko Hospital is a tertiary private health care providing centre with the highest number of work force than in any other Private tertiary hospital in Nigeria. The Eko Hospital is accredited for five various post graduate trainings by the individual national regulatory bodies and represent the pinnacle of health care services in Lagos state. The study was conducted among the female staff of the hospital between March and July, 2016. The female staffs was segmented into two sets - the medical and none medical staff.

The Eko hospitals have a total of about four hundred staff which consists of over 280 female staffs consisting of both medical and non-medical staff. Majority of the staff belong to the Yoruba and Igbo speaking tribe with very few being Hausa. There are as much Christians as there are Muslims.

Female staff of the Eko Hospitals within the age range of 16-65 years old was included in the study. Female staff of ages less than 16 years and greater than 65 years was excluded from the study. Partially or uncompleted questionnaire was excluded from the data base.

This study is a cross sectional descriptive study which was conducted in the three branches of the hospitals - (Surulere, Ikoyi and Ikeja - districts) The questionnaire consisted of 20 items and with respect to similar studies and literature reviews; the questionnaire assessed the level of perception, view, knowledge and practice of female medical and non-medical staff towards cervical cancer screening and human papilloma virus vaccination uptake.

Consent to participate in the study was sought from the female staff.

The study evaluated the cervical cancer knowledge and awareness level as well as the extent of utilisation of the Human Papilloma Virus (HPV) vaccination and cervical screening amongst female health care workers. 
It also assessed the level of experience or participation of health care workers in the private health care sector with regards to cancer public campaign enlightenment.

\section{Hypothesis tested includes}

There is a low level of cervical cancer knowledge and awareness amongst female staff of this private hospital.

There is a low level of uptake of Pap smear cervical screening and Human Papilloma Virus vaccination amongst female staff of this private hospital

There is a poor level of participation of female staff in cancer awareness campaign activities in this private hospital.

This study intends to update the knowledge of the female staffs of the hospital as well as the need to participate in Cancer awareness programmes.

It further hope to inspire individuals to participate in cervical cancer screening (Pap Smear test), and improve the choice of papilloma virus vaccine uptake.

This study didn't harm nor place any respondents at risk.

Participants was assured of the confidentiality of the data and that no co-respondents will have access to the data.

All respondent was assured of the right to withdraw from participating without any form of any discrimination or denial of any privilege

A self-administered structured questionnaire comprising of open ended and closed ended questions was used for the collection of information from the female staff and health care workers of the private hospital. The questionnaire consisted of 20 items which was designed to assess all respondents' awareness on cervical cancer, possible family history of Cervical Cancer, Human Papilloma Virus Vaccination, participation in Pap smear screening level and participation at past cancer awareness campaigns.

All non-respondents or partial respondents to any questions were excluded from the final population data. The sampling population was from Consenting female staff in all wards, units and administrative sections of the Hospital. Study participants were requested to fill a self-administered questionnaire. The language of option was English with an appeal of a maximum time line of $144 \mathrm{hrs}$ for completion and submission. The collection of the completed questions for verification was coordinated upon on or before the maximum time line span. Assistance in further clarification and filling of the questionnaire was readily available via either a flashing replied phone call or call via the official land line to the provided call lines on the questionnaire form.

The appropriate population size was calculated using Fisher's formula and Sample size calculator by raosoft (Global cancer facts and figure, 2016; Eke et al, 2010; Combating cancer in Africa, 2016) for cross-sectional study; where minimum size $(\mathrm{N})=\mathrm{Z} \mathrm{pq} / \mathrm{d}^{2}$, where the margin of error is $5 \%$, confidence level is $95 \%$, population size of 300 female staff and a $50 \%$ response distribution rate. A recommended sample size of approximately 169 was obtained but the value was increased to 200 in anticipation of non-respondents or partial respondents. Where $\mathrm{N}$ is the population size, $\mathrm{r}$ is the fraction of responses that one is interested in, and $\mathrm{Z}(\mathrm{c} / 100)$ is the critical value for the confidence level c.

In terms of the numbers selected above, the sample size $\mathrm{n}$ and margin of error $\mathrm{E}$ are given by

$\left.\mathrm{X}=\mathrm{Z}(\mathrm{c} / 100)^{2} \mathrm{r}(100-r)\right), n=N x /\left((N-1) E^{2}+x\right), E=\operatorname{Sqrt}[(N-n) x / n(N-1)]$ In handling the data analyses, all obtained data was fed into the computer statistics software. The data was presented in statistical tables. The testing of the significance for each hypothesis was analysed using Epinfo 7-statistical software.

Chi Square was used to determine the association of independent variables with the dependent variables. The level of significance was set at $p \leq 0.05$. The results were compared to other similar studies done in public hospitals.

All funds for the running cost were provided by the researcher. Individuals who were willing to enrol for cervical screening or HPV vaccine had to do so according to the hospital usual routine protocol and were responsible for the cost of Laboratory investigation.

In ensuring the quality Assurance, the following measures were taken to ensure that the result was accurate: 
The Questionnaire was designed in a simple language and was randomly tested before use.

Follow up was provided for respondents who require supports.

Potential respondents were well educated at the point of issuance of the questionnaire.

A meeting at the level of the departmental units was engaged for further quality protocol purposes. All respondent data was stored unanimously.

\section{Results}

Demographic characteristics showed that a majority of the 200 study respondents were between the age group 26-35 years which represented $101(50 \cdot 5 \%)$ of the entire study population. We observed $124(62.0 \%)$ respondents were married while $72(36.0 \%)$ were single, $166(83.0 \%)$ had a graduate degree while $19(9.5 \%)$ had obtained a postgraduate degree. Christians were $181(95.5 \%)$ while Muslim accounted for 15 (7.5\%) (Table 1).

Occupational characteristics of the study showed that the respondents consisted of $149(74.5 \%)$ medical staff and $51(25.5 \%)$ non-medical staff. Scientist and Nursing professionals accounted for the highest frequency; 34 (21.6\%) and $66(42.0 \%)$ amongst the medical staff respectively (Table 2).

Awareness of Cervical cancer by the study respondents from the data showed that 186 (93.0\%) of total respondents have heard of cervical cancer via various means however, 148 (74.0\%) of them had no knowledge of their cervical cancer status perhaps positive or not. An average of $43 \cdot 2 \%$ - (346 selected options out of expected 800) respondents had a good knowledge of the symptoms of cervical cancer and most of them were the medical staffs while about 52.3\% - (314 selected options out of expected 600) of the respondents believes that early initiation of sex, multiple sex partners and recurrent sexually transmitted diseases are the risk factors of cervical cancer. In trying to find out reasons why most of the respondents didn't take up any action to know their status, $133(66.50 \%)$ respondents complained of financial problem and fear while 48 (24.0\%) respondents chose accessibility and cultural believes as major barriers to accessing cervical screening (Table 3).

The sources of information about cervical cancer and screening from the data revealed that a majority of the respondents-129 (64.5\%), got informed about Cancer awareness/cancer screening and vaccination services-125 [62.5\%] respectively through the medical personnel (Table 4a).

The outcome of the practice of cervical cancer Screening showed that although 167 (83.5\%) had heard of Pap-Smear Laboratory investigation and 133 (66.5\%) knew of the availability of Pap smear investigation services within the Hospital facility but only 34 (17.0\%) had attempted Pap-Smear Laboratory investigation (Table 4b).

Their practice of uptake of Human Papilloma Virus- HPV Vaccination further revealed that although $159(79.5 \%)$ had heard of HPV Vaccination and 94(47.0\%) knew of the availability of HPV Vaccination services within the Hospital facility but only $43(21.5 \%)$ had attempted uptake of HPV Vaccine.

Considering that $52(26.0 \%)$ respondents knew their cervical cancer status and only $34(17 \cdot 0 \%)$ respondents attempted cervical cancer screening by Pap smear laboratory investigation specifically, the difference between respondents who had pap smear investigation and those who had attempted the HPV vaccine uptake was simply due to the exploitation of other cervical cancer screening alternatives engaged by 18 respondents upon further enquiries (Table 4c).

Their Level of Participation in CC programs showed that only about 48 (24.0\%) respondents participated between one and three programs. A majority of the $152(76.0 \%)$ respondents that never participated in any program complained of tight work schedule, non-availability of cancer seminars within the private sector, selection of participants are based on practice in public health centres and majority of the seminars are organised in the public hospitals as well as inadequate financing issues(Table 4d).

A statistical significant association was observed between cervical cancer awareness and the respondents level of education $(\mathrm{P}=0.0001<0 \cdot 05)$ - (Table 5), same was also observed between cervical cancer awareness and Occupation $(\mathrm{P}=0.00000006<0 \cdot 05)$ - (Table 6).

During the cross tabulation of their knowledge of risk factors of cervical cancer by the medical health workers and non-medical staff, the following choices of perceived cervical cancer symptoms by the medical staff respondents were statistically significant $(p<0 \cdot 05)$; early initiation of sex, 
multiple sex partners, cigarette smoking and recurrent sexually transmitted diseases but the same was not statistically significant $(\mathrm{p}>0.05)$ with the non-medical staff respondents. However, there was a statistically significant $[\mathrm{P}=0.002(\mathrm{P}<0.05), \mathrm{P}=0.015(\mathrm{P}<0.05)]$ number of respondents who had no idea about the symptoms of cervical cancer in both categories respectively - (Table 7).

The known risk factors for cervical cancer includes early initiation of sex, multiple sex partners, multiple births, vaginal douching, cigarette smoking, recurrent STDs and excess alcohol drinking. In an open ended survey questions, the evaluation of the relationship between awareness of cervical cancer and the Various Medical Health workers revealed a significant awareness level of cervical cancer amongst the medical health workers $(\mathrm{P}=0 \cdot 016, \mathrm{P}<0 \cdot 05)$ - (Table 8$)$.

Upon testing the relationship between their level of participation in CC programs and their general attitude towards their CC status, there was a significant association showing that a possible increased participation in cancer awareness programs by the study respondents, would lead to; Increase in knowledge of CC status $(\mathrm{p}=0.006<0.05)$ and increase in utilization of Pap smear test $(\mathrm{p}=0 \cdot 0009<0 \cdot 05)$ as well as improved uptake of HPV vaccine $(\mathrm{p}=0.006<0 \cdot 05)-($ Table $9 \mathrm{~b})$.

\section{Tables}

Table 1. Demographic characteristics of study participants

\begin{tabular}{|c|c|c|}
\hline \multicolumn{3}{|c|}{ Demographic characteristics of study participants } \\
\hline Variable & Frequency & Outcome (\%) \\
\hline \multicolumn{3}{|l|}{ Age (Years } \\
\hline Mean & 48 & \\
\hline Range & $(16-65)$ & \\
\hline \multicolumn{3}{|c|}{ Age group (Years) } \\
\hline $16-25$ & 37 & 18.5 \\
\hline $26-35$ & 101 & 50.5 \\
\hline $36-45$ & 35 & 17.5 \\
\hline $46-55$ & 20 & 10.0 \\
\hline $55-65$ & 7 & 3.50 \\
\hline$\geq 65$ & 0 & 0.00 \\
\hline TOTAL & 200 & $100.00 \%$ \\
\hline \multicolumn{3}{|l|}{ Marital Status } \\
\hline Single & 72 & 36.00 \\
\hline Married & 124 & 62.00 \\
\hline Widow & 2 & 1.00 \\
\hline Separated & 1 & 0.50 \\
\hline Divorced & 1 & 0.50 \\
\hline TOTAL & 200 & $100.00 \%$ \\
\hline \multicolumn{3}{|c|}{ Level of Education } \\
\hline Secondary & 15 & 7.5 \\
\hline Graduate & 166 & 83.0 \\
\hline Post-Graduate & 19 & 9.5 \\
\hline TOTAL & 200 & $100.00 \%$ \\
\hline \multicolumn{3}{|l|}{ Religion } \\
\hline Catholic & 15 & 7.50 \\
\hline Anglican & 15 & 7.50 \\
\hline Methodist & 21 & 10.50 \\
\hline Pentecostal & 114 & 57.00 \\
\hline Muslim & 15 & 7.50 \\
\hline Baptism & 16 & 8.00 \\
\hline Others & 4 & 2.00 \\
\hline TOTAL & 200 & $100.00 \%$ \\
\hline
\end{tabular}


DOI: $10.21522 /$ TIJPH.2013.06.01.Art006

ISSN: $2520-3134$

Table 2. Occupational characteristics of all the study participants

\begin{tabular}{|l|l|l|}
\hline Occupational characteristics of all the study participants \\
\hline Variable & Frequency & Outcome (\%) \\
\hline Occupation & 149 & 74.5 \\
\hline Medical Staff & 51 & 25.5 \\
\hline Non-Medical staff & 200 & $100.00 \%$ \\
\hline TOTAL & 14 & 8.92 \\
\hline Distribution of Occupation-Medical staff (\%) \\
\hline Radiologist & 12 & 7.64 \\
\hline Pharmacist & 12 & 21.6 \\
\hline Scientist & 34 & 42.04 \\
\hline Nurse & 66 & 13.38 \\
\hline Doctor & 21 & 6.37 \\
\hline Others & 10 & $100 \%$ \\
\hline TOTAL & 157 & 27.90 \\
\hline Distribution of Occupation -Non Medical staff $\mathbf{~ ) ~}$ \\
\hline Accountant & 12 & 32.55 \\
\hline Administrators & 14 & 18.60 \\
\hline House Keepers & 8 & 20.90 \\
\hline Others & 9 & $100 \%$ \\
\hline TOTAL & 43 &
\end{tabular}

Table 3. Awareness of cervical cancer (CC)

\begin{tabular}{|l|l|l|}
\hline Awareness of Cervical Cancer-(CC) \\
\hline Variable & Frequency & Outcome (\%) \\
\hline Knowledge of CC. & 186 & 93.00 \\
\hline Yes & 14 & 7.0 \\
\hline No & 52 & 26 \\
\hline Knowledge of CC Status. \\
\hline Yes & 148 & 74 \\
\hline No & \multicolumn{3}{|l|}{} \\
\hline Perceived symptoms of CC. & 50.00 \\
\hline Vaginal Bleeding & 100 & 48.00 \\
\hline Postcoital bleeding & 96 & 46.00 \\
\hline Vaginal discharge & 92 & 29.00 \\
\hline Lower abdominal pain & 58 & 23.00 \\
\hline I don't know & 46 & 1.50 \\
\hline None of the above & 3 & 50.50 \\
\hline Perceived risk factors of CC. & 101 & 57.00 \\
\hline Early initiation of sex & 114 & 17.00 \\
\hline Multiple sex partners & 114 & 17.50 \\
\hline Multiple births & 34 & 13.00 \\
\hline Vaginal douching & 35 & 49.50 \\
\hline Cigarette smoking & 26 & 4.50 \\
\hline Recurrent STD & 99 & \\
\hline Excess alcohol drinking & 9 & \\
\hline
\end{tabular}


Texila International Journal of Public Health Volume 6, Issue 1, Feb 2018

\begin{tabular}{|l|l|l|}
\hline I don't know & 53 & 26.50 \\
\hline None of the above & 6 & 3.0 \\
\hline \multicolumn{2}{|l|}{ Perceived barriers to CC Screening. } \\
\hline Transportation & 10 & 5.00 \\
\hline Financial problem & 133 & 66.50 \\
\hline Fear & 131 & 65.50 \\
\hline Staff attitude & 19 & 9.50 \\
\hline Accessibility & 48 & 24.00 \\
\hline Occupation & 12 & 6.00 \\
\hline Cultural believes & 52 & 26.00 \\
\hline None availability & 17 & 8.50 \\
\hline
\end{tabular}

Table 4a. Source of information about cervical cancer awareness

\begin{tabular}{|l|l|l|}
\hline \multicolumn{3}{|l|}{ Source of information about cervical cancer awareness } \\
\hline Variable & Frequency & Outcome (\%) \\
\hline Source of information about Pap-Smear test \\
\hline Friends & 23 & 11.50 \\
\hline Co-staff & 50 & 25.00 \\
\hline Medical personnel & 129 & 64.50 \\
\hline Mass media & 34 & 17.00 \\
\hline Church & 9 & 4.50 \\
\hline Book & 38 & 19.00 \\
\hline Internet & 21 & 10.50 \\
\hline Source of information about HPV Vaccination \\
\hline Friends & 23 & 11.50 \\
\hline Co-staff & 40 & 20.00 \\
\hline Medical personnel & 125 & 62.50 \\
\hline Mass media & 30 & 15.00 \\
\hline Church & 6 & 3.00 \\
\hline Book & 27 & 13.50 \\
\hline Internet & 27 & 13.50 \\
\hline
\end{tabular}

Table 4b. Practice of cervical cancer pap-smear screening

\begin{tabular}{|c|c|c|}
\hline \multicolumn{3}{|c|}{ Practice of cervical cancer pap-smear screening } \\
\hline Variable & Frequency & Outcome $(\%)$ \\
\hline \multicolumn{3}{|c|}{ Heard of Pap-Smear laboratory investigation } \\
\hline Yes & 167 & 83.50 \\
\hline No & 33 & 16.50 \\
\hline \multicolumn{3}{|c|}{ Attempt of Pap-Smear Laboratory investigation } \\
\hline Yes & 34 & 17.00 \\
\hline No & 166 & 83.00 \\
\hline \multicolumn{3}{|c|}{$\begin{array}{l}\text { Awareness of Pap smear investigation services within th } \\
\text { Hospital facility }\end{array}$} \\
\hline Yes & 133 & 66.50 \\
\hline No & 67 & 33.50 \\
\hline
\end{tabular}


DOI: $10.21522 /$ TIJPH.2013.06.01.Art006

ISSN: $2520-3134$

Table 4c. Practice of uptake of human papilloma virus (HPV)

\begin{tabular}{|l|c|c|}
\hline \multicolumn{3}{|c|}{ Practice of cervical cancer pap-smear screening } \\
\hline Variable & Frequency & Outcome (\%) \\
\hline \multicolumn{3}{|c|}{ Heard of HPV Vaccination. } \\
\hline Yes & 159 & 79.50 \\
\hline No & 41 & 20.00 \\
\hline Attempt uptake of HPV Vaccine \\
\hline Yes & 43 & 21.50 \\
\hline No & 157 & 78.50 \\
\hline $\begin{array}{l}\text { Awareness of HPV Vaccination services within the } \\
\text { Hospital facility }\end{array}$ \\
\hline No & 94 & 47.00 \\
\hline Yes & 43 & 53.00 \\
\hline
\end{tabular}

Table 4d. Level of participation in CC programs

\begin{tabular}{|l|l|l|}
\hline \multicolumn{3}{|c|}{ Level of participation in CC programs } \\
\hline Variable & Frequency & Outcome (\%) \\
\hline Nil & 152 & 76.00 \\
\hline Once & 31 & 15.50 \\
\hline Thrice & 15 & 7.50 \\
\hline$\geq$ Thrice & 2 & 1.00 \\
\hline
\end{tabular}

Table 5. Cross tabulation of awareness of cervical cancer with the demographic characteristics of the respondents

\begin{tabular}{|c|c|c|c|}
\hline \multicolumn{4}{|c|}{$\begin{array}{l}\text { Cross tabulation of awareness of cervical cancer with the } \\
\text { demographic characteristics of the respondents }\end{array}$} \\
\hline \multirow[t]{2}{*}{ Variable } & \multicolumn{2}{|c|}{ Frequency } & \multirow{2}{*}{$\begin{array}{l}\text { Test Statistics } \\
\text { (Chi-Square) } \\
\end{array}$} \\
\hline & Yes & No & \\
\hline \multicolumn{4}{|c|}{ Age group (Years) } \\
\hline $16-25$ & 33 & 4 & \multirow{6}{*}{$\begin{array}{l}X^{2}=6.3, P=0.17, d f=4 \\
P>0.05\end{array}$} \\
\hline $26-35$ & 96 & 5 & \\
\hline $36-45$ & 30 & 5 & \\
\hline $46-55$ & 20 & 0 & \\
\hline $55-65$ & 7 & 0 & \\
\hline$\geq 65$ & 0 & 0 & \\
\hline \multicolumn{4}{|l|}{ Marital Status } \\
\hline Single & 65 & 7 & \multirow{5}{*}{$\begin{array}{l}\mathrm{X}^{2}=1.4, \mathrm{P}=0.8, \mathrm{df}=4 \\
\mathrm{P}>0.05\end{array}$} \\
\hline Married & 117 & 7 & \\
\hline Widow & 2 & 0 & \\
\hline Separated & 1 & 0 & \\
\hline Divorced & 1 & 0 & \\
\hline \multicolumn{4}{|c|}{ Level of Education } \\
\hline Secondary & 10 & 5 & \multirow{3}{*}{$\begin{array}{l}X^{2}=18.0, P=0.0001, d f=4 \\
P>0.05\end{array}$} \\
\hline Graduate & 157 & 9 & \\
\hline Post-Graduate & 19 & 0 & \\
\hline
\end{tabular}


Table 6. Cross tabulation of awareness of cervical cancer with the occupation

\begin{tabular}{|c|c|c|c|}
\hline \multicolumn{4}{|c|}{$\begin{array}{l}\text { Cross tabulation of awareness of cervical cancer with the } \\
\text { occupation. }\end{array}$} \\
\hline \multirow{2}{*}{ Variable } & \multicolumn{2}{|c|}{ Frequency } & \multirow{2}{*}{$\begin{array}{l}\text { Test Statistics } \\
\text { (Fisher Exact) }\end{array}$} \\
\hline & Yes & No & \\
\hline \multicolumn{4}{|l|}{ Occupation } \\
\hline Medical Staff & 148 & 1 & \multirow{2}{*}{$\begin{array}{l}\mathrm{X}^{2}=32.2, \mathrm{P}=0.00000006, \mathrm{~d} \\
=5 \\
(\mathrm{P}<0.05)\end{array}$} \\
\hline Non-Medical staff & 38 & 13 & \\
\hline
\end{tabular}

Table 7. Cross tabulation of knowledge of risk factors cervical cancer with the medical health workers and nonmedical staff

\begin{tabular}{|l|l|l|l|}
\hline \multicolumn{3}{|l|}{$\begin{array}{l}\text { Cross tabulation of knowledge of risk factors cervical cancer with the } \\
\text { medical health workers and non-medical staff. }\end{array}$} \\
\hline Variable & Frequency & Test Statistics \\
\hline Medical staff & Yes & No & $($ Chi-Square $)$ \\
\hline $\begin{array}{l}\text { Early initiation of } \\
\text { sex }\end{array}$ & 91 & 66 & $\begin{array}{l}\mathrm{X}^{2}=26.14, \mathrm{df}=5, \mathrm{P}=0.0001 \\
(\mathrm{P}<0.05)\end{array}$ \\
\hline Multiple sex partners & 101 & 56 & $\begin{array}{l}\mathrm{X}^{2}=21.02, \mathrm{df}=5, \mathrm{P}=0.0008 \\
(\mathrm{P}<0.05)\end{array}$ \\
\hline Multiple births & 31 & 126 & $\mathrm{X}^{2}=10.60, \mathrm{df}=5, \mathrm{P}=0.059(\mathrm{P}>0.05)$ \\
\hline Vaginal douching & 33 & 124 & $\mathrm{X}^{2}=10.07, \mathrm{df}=5, \mathrm{P}=0.071(\mathrm{P}>0.05)$ \\
\hline Cigarette smoking & 22 & 135 & $\mathrm{X}^{2}=18.81, \mathrm{df}=5, \mathrm{P}=0.002(\mathrm{P}<0.05)$ \\
\hline Recurrent STD & 87 & 70 & $\mathrm{X}^{2}=21.28, \mathrm{df}=5, \mathrm{P}=0.007(\mathrm{P}<0.05)$ \\
\hline $\begin{array}{l}\text { Excess alcohol } \\
\text { drinking }\end{array}$ & 5 & 152 & $\mathrm{X}^{2}=10.70, \mathrm{df}=5, \mathrm{P}=0.057(\mathrm{P}>0.05)$ \\
\hline I don't know & 28 & 129 & $\mathrm{X}^{2}=18.45, \mathrm{df}=5, \mathrm{P}=0.002(\mathrm{P}<0.05)$ \\
\hline None of the above & 2 & 155 & $\mathrm{X}^{2}=7.13, \mathrm{df}=5, \mathrm{P}=0.211(\mathrm{P}>0.05)$ \\
\hline Non-Medical staff & Yes & $\mathrm{No}$ & $($ Chi-Square $)$ \\
\hline $\begin{array}{l}\text { Early initiation of } \\
\text { sex }\end{array}$ & 11 & 40 & $\mathrm{X}^{2}=1.03, \mathrm{df}=3, \mathrm{P}=0.793(\mathrm{P}>0.05)$ \\
\hline Multiple sex partners & 14 & 37 & $\mathrm{X}^{2}=0.37, \mathrm{df}=3, \mathrm{P}=0.945(\mathrm{P}>0.05)$ \\
\hline Multiple births & 3 & 48 & $\mathrm{X}^{2}=1.42, \mathrm{df}=3, \mathrm{P}=0.700(\mathrm{P}>0.05)$ \\
\hline Vaginal douching & 3 & 48 & $\mathrm{X}^{2}=3.89, \mathrm{df}=3, \mathrm{P}=0.272(\mathrm{P}>0.05)$ \\
\hline Cigarette smoking & 4 & 47 & $\mathrm{X}^{2}=6.84, \mathrm{df}=3, \mathrm{P}=0.076(\mathrm{P}>0.05)$ \\
\hline Recurrent STD & 14 & 37 & $\mathrm{X}^{2}=3.85, \mathrm{df}=3, \mathrm{P}=0.277(\mathrm{P}>0.05)$ \\
\hline $\begin{array}{l}\text { Excess alcohol } \\
\text { drinking }\end{array}$ & 4 & 47 & $\mathrm{X}^{2}=7.76, \mathrm{df}=3, \mathrm{P}=0.051(\mathrm{P}=0.05)$ \\
\hline I don't know & 22 & 29 & $\mathrm{X}^{2}=10.38, \mathrm{df}=3, \mathrm{P}=0.015(\mathrm{P}<0.05)$ \\
\hline None of the above & 2 & 49 & $\mathrm{X}^{2}=4.16, \mathrm{df}=5, \mathrm{P}=0.244(\mathrm{P}>0.05)$ \\
\hline
\end{tabular}

Table 8a. Cross tabulation of awareness of cervical cancer with the various Medical Health workers

\begin{tabular}{|l|l|l|l|}
\hline $\begin{array}{l}\text { Cross tabulation of awareness of cervical cancer } \\
\text { with the various Medical Health workers }\end{array}$ \\
\hline Variable & \multicolumn{1}{|c|}{ Frequency } & Test Statistics \\
\hline & Yes & No & (Chi-Square) \\
\hline Medical staff & & & \\
\hline Radiologist & 14 & 0 & $\begin{array}{l}\mathrm{X}^{2}=13 \cdot 8, \\
\mathrm{P}=0.016, \mathrm{df}=5,\end{array}$ \\
\hline Pharmacist & 12 & 0 & $\mathrm{l}$
\end{tabular}


DOI: $10.21522 /$ TIJPH.2013.06.01.Art006

ISSN: $2520-3134$

\begin{tabular}{|c|c|c|c|}
\hline Scientist & 33 & 1 & \multirow[t]{5}{*}{$(\mathrm{P}<0.05)$} \\
\hline Nurse & 65 & 1 & \\
\hline Doctor & 21 & 1 & \\
\hline Others & 8 & 2 & \\
\hline TOTAL & 153 & 4 & \\
\hline \multicolumn{4}{|c|}{ Non-Medical staff } \\
\hline Accountant & 9 & 3 & \multirow{5}{*}{$\begin{array}{l}X^{2}=7 \cdot 5, \\
P=0.05, d f=3, \\
(P<0.05)\end{array}$} \\
\hline Administrators & 11 & 3 & \\
\hline House Keepers & 3 & 5 & \\
\hline Others & 15 & 2 & \\
\hline TOTAL & 38 & 13 & \\
\hline
\end{tabular}

Table 8b. Cross tabulation of knowledge of cervical cancer status with the various medical health workers

\begin{tabular}{|c|c|c|c|}
\hline \multicolumn{4}{|c|}{$\begin{array}{l}\text { Cross tabulation of Knowledge of Cervical } \\
\text { Cancer Status with the Various Medical Health } \\
\text { workers. }\end{array}$} \\
\hline \multirow[t]{2}{*}{ Variable } & \multicolumn{2}{|c|}{ Frequency } & \multirow{2}{*}{$\begin{array}{l}\text { Test Statistics } \\
\text { (Chi-Square) }\end{array}$} \\
\hline & Yes & No & \\
\hline \multicolumn{4}{|c|}{ Medical staff } \\
\hline Radiologist & 6 & 8 & \multirow{7}{*}{$\begin{array}{l}\mathrm{X}^{2}=11.7, \mathrm{P}= \\
0.3, \mathrm{df}=10 \\
(\mathrm{P}>0.05)\end{array}$} \\
\hline Pharmacist & 5 & 7 & \\
\hline Scientist & 8 & 26 & \\
\hline Nurse & 16 & 50 & \\
\hline Doctor & 11 & 10 & \\
\hline Others & 3 & 7 & \\
\hline TOTAL & 49 & 108 & \\
\hline
\end{tabular}

Table 9a. Cross tabulation of participation in cervical cancer programs with the various medical health workers

Cross tabulation of participation in cervical cancer programs with the various medical health workers.

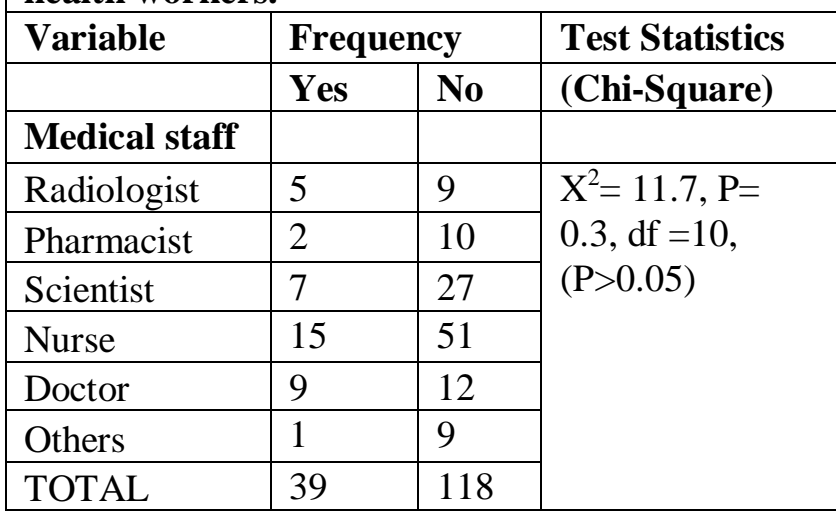


Table 9b. Cross tabulation of level of participation in CC programs and CC practice

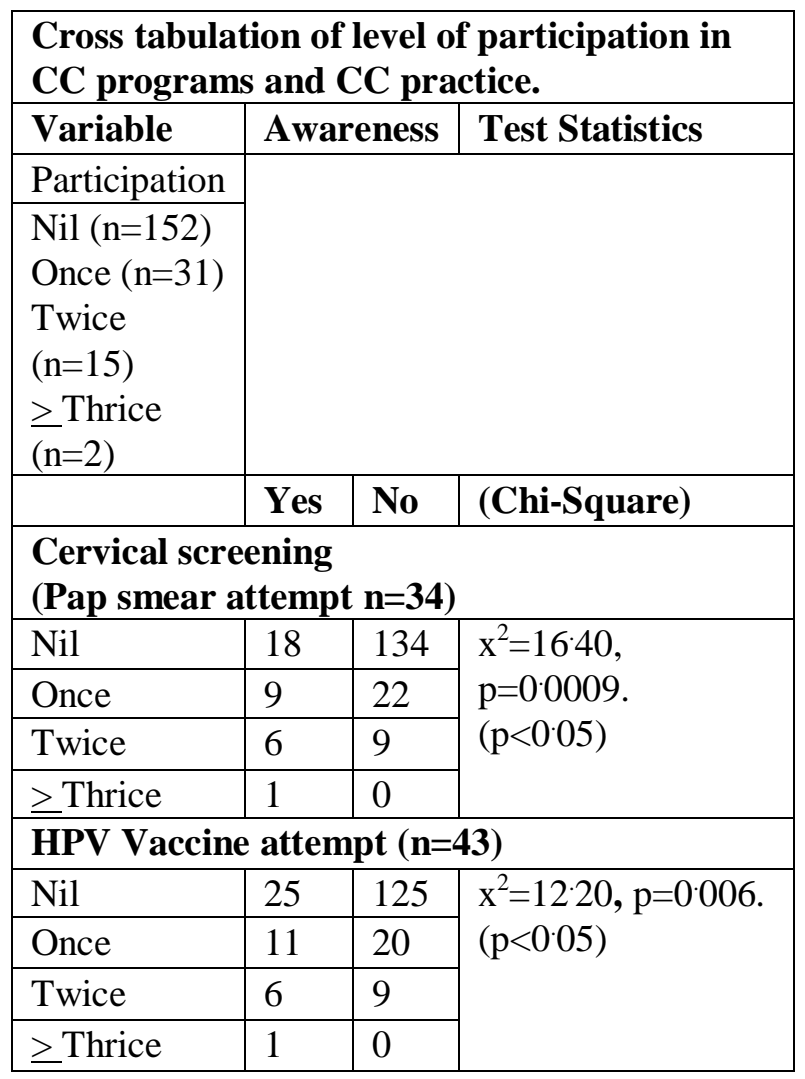

\section{Discussion}

The larger proportion of the study participants were amongst the vibrant and energetic age-group of 26-35 years. This outcome was similar to another research reported in Kumasi Ghana (Williams et al, 2013) and could perhaps just be by chance following the age policy criteria for employment by the hospital board as the study did not show any statistical significant association between age of respondents and awareness of cervical cancer.

Various reports in Lagos Nigeria, Ghana (Williams et al, 2013), Ekiti Nigeria (Akintoye et al, 2013) and Nnewi Nigeria (Eke et al, 2010), had similar trends as well.

It didn't matter whether they were married or not, there was really no statistical association between awareness of cervical cancer and marital status and this same trend was reported in similar research done in(Williams et al, 2013) and Nnewi Nigeria (Eke et al, 2010).

Although a greater proportion of the study participants had a high level of education, however the study showed a statistical association between their level of awareness of cervical cancer and educational level which further reveals that enhanced formal education or literacy within the public is crucial to the attainment of the expected awareness level. This outcome was similar to various reports in Lagos Nigeria, Ghana (Williams et al, 2013), Ekiti Nigeria (Akintoye et al, 2013), and Nnewi Nigeria (Eke et al, 2010). The effect of the literacy impact was observed in the level of awareness in comparison between the core health workers and the non-medical health workers. Although a general high level of awareness of cervical cancer was observed amongst the study participants however, there was a statistically significant level of awareness among the medical health workers compared to the non-medical health workers group which was not statistically significant. The knowledge of the symptoms of cervical cancer was again high amongst the majority of the medical staff. This trend was also reported in Nnewi Nigeria (Eke et al, 2010). This agrees to the fact that the medical health workers in the private sector are also equipped knowledge wise in the awareness of cervical cancer. Going by the fact that the non-medical health workers are constantly in synergy with the medical health workers, the low level of awareness among the non-medical health workers was not expected however, it suggests the need by the well informed medical health workers to ensure the 
dissemination of the required information about cervical cancer disease to other non-medical staff. The use of leaflets and a periodic health awareness official gathering are important means of enhancing awareness levels too.

This study revealed a low level of cervical cancer screening practice amongst health workers. From the $93 \%$ of total respondents that have heard about the disease, a total of $74 \%$ have no knowledge of their cervical cancer status. However, in comparison with few interesting studies in Nigeria, this study shows a relatively high level of awareness and practice of cervical cancer screening compared to other figures such as in the study done in Port Harcourt, Nigeria (Babatunde et al, 2005). Similar trends were reported in Ghana (Williams et al, 2013) and Nnewi Nigeria (Eke et al, 2010). This further attests to the fact that the medical health workers in the private sector are also relatively equipped knowledge wise in the awareness of cervical cancer.

The reasons for the low turn out as shown by this study includes financial problem, fear, accessibility problem and cultural believes as major barriers to accessing cervical screening In addition, other reasons explained in another study included cultural believes and staff attitude (Arevian et al, 2006).

In a report by the Atomic energy agency, fear and taboos could lead to lack of decision to utilise cancer screening' which then means that most patients will seek help when it is already too late and the biggest challenge is late presentation; it is a huge one (Arevian et al, 2006)..

In tackling accessibility problems, much emphasis needs to be placed on the support of private health facilities within the rural areas in terms of investing in cervical screening facilities because "a lack of preventive, diagnostic and treatment facilities means that literally millions of people are dying whose lives would be prolonged or even saved if they happened to live in the developed world (Arevian et al, 2006)." it is reported in another study in Ghana(Williams et al, 2013) that the respondents who had obtained a cervical cancer screening only did it as a result of a physician's recommendation and also out of fear.

A good health insurance scheme is the most successful means of tackling the financial problem. It is much easier for persons under an insurance health scheme to easily pay for cervical cancer screening. A similar study reported on the importance of health insurance scheme relative to cancer disease (Babatunde et al, 2005). Another study revealed that the financial burden was majorly as a result of the high cost of transport fare to long distances for cervical cancer screening and routine check centres in the cities (Arevian et al, 2006).This can be reduced greatly if approved Cervical Cancer screening centres were around the rural areas. In another report, a physician reported that "Even when they come and we want to treat the patient, there is the issue of finance, we have a lot of patients we can do something for, but they will tell you 'sorry doctor, there is no money (Arevian et al, 2006; National cancer institute, 2016)".

There was generally a high level of knowledge of both symptoms and risk factors especially among the medical staff. A similar study reported that the commonly known risk factors for cervical cancer were multiple sexual partners and sexually transmitted infections (Eke et al, 2010). However, this study revealed further that the following choices of perceived cervical cancer symptoms by the medical staff participants were statistically significant; early initiation of sex, multiple sex partners, cigarette smoking and recurrent sexually transmitted diseases but the same was not statistically significant with the non-medical staff respondents. A study reported that the knowledge of Cervical Cancer was significantly highest among health workers and this finding is similar to that also done in Uganda (Mutyaba et al, 2006). We further observed that the major sources of information with regards to cervical cancer awareness/cancer screening services and HPV vaccination in this study were medical personnel, Co-Staff and the Mass media. In a similar study in Ibadan Nigeria, the sources of information about the disease revealed that a majority of the study participant became aware of the disease through the media and from health workers (Arulogun et al, 2012). This further affirms that the medical health workers are knowledgable and posses an inspiring attitudinal level. It is a further reason for confidence in the private sector health workers in Nigeria which will inturn provide the right motivation and incentives for both the health workers and the potential private health care consumer. This is positive for the primary role of enhancing the public awareness on cancer diseases. 
This study showed a non-significant turn out of health workers in cervical cancer screening attempt. This outcome was different from the outcome of a similar study in Nigeria (Olowookere et al, 2012), where the uptake of cervical screening; awareness, willingness, and practice of cervical cancer screening was relatively high compared to other similar research figures in Nigeria. It is notable that a majority of this study respondents whom have attempted pap-smear cancer screening or perhaps any other convenient cervical screening method did utilize the uptake of HPV vaccination.

There was a non-significant but high level of practice of attitude and uptake of HPV vaccination in this study.

Surprisingly, a majority of the study participants had never attended a cancer awareness program before except for a few who only attended at least one program. Most respondents that never participated in any program complained of tight work schedule, non-availability of cancer seminars within the private sector. A few pointed out that the selection of participants in public health organized cancer seminars were based on practicing staff members and majority of the seminars are organised in far distant public hospitals coupled with inadequate financing issues.

This study showed a significant link illustrating that a possible increased participation in cancer awareness programs by the study respondents, would lead to; Increase in knowledge of CC status $(\mathrm{p}=0 \bullet 006<0 \bullet 05)$, increase in utilization of Pap smear test $(\mathrm{p}=0 \bullet 0009<0 \bullet 05)$, and improved uptake of HPV vaccine $(\mathrm{p}=0 \bullet 006<0 \bullet 05)$. It is important that cancer awareness should be on the increase at all levels of governance.

\section{Conclusion}

This study, in all ramifications with other studies and in comparison with the public health sector outside Lagos State has shown that there is a significant level of awareness of cervical cancer amongst the female health workers in the private health sector. The level of awareness is strongly associated with enhanced education but there was no link with age or marital status. It also reveals a significant link between the level of awareness and health occupation especially the core health workers. However, there was a marginal link with the non-medical health workers. Furthermore, there was a significant link illustrating that a possible increased participation in cancer awareness programs would lead to; Increase in knowledge of CC status, increase in utilization of Pap smear test and improved uptake of HPV vaccine. This outcome serves as an original article data base to resolve any doubt and perception on the level of knowledge and awareness of Cervical Cancer amongst private sector health workers in Lagos state and extendable to Nigeria.

In lieu of the vast presence of geographical distribution of populace in the urban and rural communities in Lagos, Nigeria, and coupled with the presence of insufficient health workers in the public health institutions, the fight against the scourge of cancer could remain unsuccessful. However, a deliberate strategic involvement of the private sector health workers would provide a useful expanded reach to the populace. This is not largely the case in most government policy interventions therefore as a recommendation, there is a crucial need to research a further case with evidence for the immense active engagement of the Private sector health workers in the governments' policy drive and intervention plan for Nigerias' future strategic cancer prevention program.

\section{References}

[1]. AA. Akintoye, RO Olowolayemo, OG Olomojobi, GA Seluwa, OO Akintayo, OB Fasubaa. Awareness of cervical cancer and its prevention among young women in Ekiti state, south-west Nigeria: tropical journal of Obstetrics and Gynaecology: Vol 30, No 2 (2013)

[2]. Adebamowo, C.A \& Ajayi O.O. (2000) Breast cancer in Nigeria. West African journal medicine 19,179194.

[3]. Ajayi I.O, Onibokun A.C, Soyannwo O.A. Breast and Cervical cancers awareness and screening practices among rural women in Ona-ara Local Government Area, Ibadan, Nigeria. Afr. J. Biomed. Res. Vol.16 (May 2013); $95-99$.

[4]. All about cancer: http://www.medicalnewstoday.com/info/cancer-oncology/. Accessed at 6:38pm on the $15^{\text {th }}$ of January, 2016. 
[5]. Alliance for cervical cancer prevention. Cervical cancer prevention fact sheet. Risk factors of cervical cancer: evidence to date, May 2004. Available from: http://www.path.org/files/RH_fs_risk_factors .pdf; accessed at 6:00pm January 2010

[6]. Anderson GH, Boyes DA, Benedet JL, Riche JC, Matisic JP, Srien K.C, Worth AJ, Millner A and Bennett OM. Organization and results of the cervical cytology screening programme in British Columbia, 1955-85 $\mathrm{Br}$ Med J (clin. Res. Ed.) 1988; 296:975-978

[7]. Anorlu RI. Tumours of the cervix uteri. In: text book of Obstetrics and Gynaecology for Medical Students. 2nd edition (Ed Agboola A.) Heinemann Educational Books (Nigeria) Plc, Ibadan. 2006: 2:167-182.

[8]. Arbyn M, Castellsagué X, de Sanjosé S, Bruni L, Saraiya M, Bray F, Ferlay J. Worldwide burden of cervical cancer in 2008. Ann Oncol 2011; 22:2675-2686.

[9]. Arevian M, Nouredrine. S, Kabakian - khasholian T. Raising awareness and providing free screeming among economically disadvantaged Lebanese/Armenian women. In: Journal of Transcultural mirsing vol. 17:No.4, October 2006:357-364.

[10]. Arulogun O.S. and Maxwell O.O. (2012): Perception and utilization of cervical cancer screening services among female nurses in University College Hospital, Ibadan, Nigeria. The Pan African Medical Journal. 11,69.

[11]. Awareness and uptake of Human papilloma virus vaccination and cervical screening among female undergraduate students in a tertiary institution in Nigeria. Journal of family Practice, Vol3, Nol (2012).

[12]. Ayinde OA, Omigbodun AO, Hesanmi AO. Awareness of cervical cancver, Papamicolaous smear and its utilization among female undergraduates in Ibandan. Afr J Repro Health 2004; 8:68-80

[13]. Ayinde, O.A, Omigbodun A.O, Knowledge, attitude and practices related to prevention of cancer of the cervix among female health workers in Ibandan. In: Journal of Obstetrics and Gynaecology volume 23: No.1, January 2003:59-62.

[14]. Balogun MR, Odukoya OO, Oyediran MA and Ujomu PI. Cervical Cancer Awareness and Preventive Practices: A Challenge for Female Urban Slum Dwellers in Lagos, Nigeria. African Journal of Reproductive Health March 2012; 16(1): 75.

[15]. Barry J, Breen N. The importance of place of residence in predicting late-stage diagnosis of breast, Health \& Place, 2005; 11(1):15-29

[16]. Behbakht K, Lynch A, Teal S, Degeest K, Massad S. Social and Cultural Barriers to Papanicolaou Test Screening in an Urban Population. Obstetrics and Gynaecololgy. 2004; 104(6):1355-61.

[17]. Bekkers R.L., Meijer C.J., Massuger L.F., Snijders P.J., Melchers W.J. (2006) Effects of HPV detection in population-based screening programmes for cervical cancer; a Dutch moment. GynecolOncol. 100, 451-4.

[18]. Bjorn Lomborg, How healthy is the world? In British medical journal, 2002 December 21:325(7378): 1461-1466.

[19]. Bray F., Ren J.S., Masuyer E., Ferlay J. (2013).Global estimates of cancer prevalence for 27 sites in the adult population in 2008. Int J Cancer, 132, 1133-1145.

[20]. Cervical cancer prevention. (http://www.rho.org/1/ REVISE/RHO \% 20 backup/ RHO\%20web\%20files/ $\mathrm{html} / \mathrm{cxc}$ a. htm. Accessed at 4:30pm on the $12^{\text {th }}$ of January, 2016

[21]. Claeys P, De Vnyst H, Gonzalez C, Garcia A, Bello R.E, Temmerman M. Performance of the acetic acid test when rised in field conditions as a screening test for cervical cancer. In: Tropical Medicine and International Health. Vol.8: August 2003:704.

[22]. Combating cancer in Africa- International Atomic energy agency. http://www.iaea.org/news/combatingcancer-Africa.com. Accessed on the $15^{\text {th }}$ January, 2016.

[23]. Coughlin SS, King J, Richards TB et al. Cervical cancer screening among women in metropolitan areas of the United States by individual-level and area-based measures of socioeconomic status, 2000 to 2002.

[24]. Eke NO, Ezeama C, Eke CO, Eleje GU, Akabuike JC, Ezebialu. Knowledge of cervical cancer and its screening amongst Female workers in Nnewi, Nigeria. AfrimedicJournal2010;1 (1):31-36.

[25]. Ezem B.u. (2007) Awareness and uptake of cervical cancer screening in Owerri, SouthEastern Nigeria, Annals of African Medicine 6, 94-8.

[26]. F.A. Ziba, P.Baffoe, P.P.M. Dapere, S.o. Shittu and B.B. Antuamwine. Awareness and knowledge level of cervical cancer among women of reproductive age in Bolgatange municipality; journal of medical and Biomedical Sciences (2015)4(2):1-6. doi: http:/ / dx.doi.org/ 10.4314/ jmbs.v4i2.1 
[27]. Ferlay, j, Bray, f, Pisam, P and Parkim, D.M. (2004). Globocan 2002 Cancer Incidence, Mortality and prevalence worldwide. No.5 version 2.0. Lyon, France international agency for research on cancer press (IARC), 2004.

[28]. Gharoro E.P, Ikeanyi E.N. An appraisal of the level of awareness and utilization of the Pap smear as a cervical screening test among female health workers in a tertiary health institution. In: Int J Gynecol Cancer 2006; 16:10631068.

[29]. Global cancer facts and figure, http://www.cancer.org/acs/groups/content/ @epidermologysurveillance document/document/acspc-027766.pdf. Accessed at 6:00pm on the $15^{\text {th }}$ of January, 2016.

[30]. GLOBOCAN. (2008): Cancer Incidence and Mortality Worldwide in. International Agency on Research for Cancer. Available from: http:// globocan.iarc.fr/. Accessed at 6:08am December 23, 2015.

[31]. Hakama M, Joutsenlahti U, Virtaren A, et al. Mass screening for cervical cancer in finland 1963-71. Organisation, extent and epidemiological implications. Ann clin Res 1975; 7:101-111

[32]. M.H. Simaubi, M.C. Ngoma. Cervical cancer awareness and uptake of Pap- Smear Services among women above 18 years of Age, Medical Journal of Zambia, vol.40, No.1 (2013)

[33]. Mityaba T, Mimiro F.A, weiderpass E. knowledge, attitudes and practices. On cervical cancer screening among the medical workers of mulayo Hospital, Uganda. In: BMC Med Educ. 2006; 6:13.

[34]. Mostly medical, Nursing and Applied health dictionary.CV mostly Company 1990, $3^{\text {rd }}$ edition 235.

[35]. Mwanahamintin, M. (2008). Cervical cancer screening. File //c: documents and settings/james/ my Documents/CIDRZ accessed on $14^{\text {th }}$ August 2015.

[36]. National cancer institute. http://www.cancer.gov/. Accessed on the $16^{\text {th }}$ of January, 2016.

[37]. Ngoma T. world Health Organization cancer priorities in developing countries. Ann. Oncol. 2006;17(Suppl.8), viiig-viii14.

[38]. Oboma YJS and Onyije FM. Cervical cancer: An emerging Public health issue in Bayelsa state metropolis. J phys pharm Adv 2012; 2:133-135.

[39]. Okonofua (2007) HPV vaccine and prevention of cervical cancer in African. African journal of Reproductive health 2, 7-12.

[40]. Owoeye I.O.G, Ibrahim .I.A. Knowledge and attitude towards cervical cancer screening among female students and staff in a tertiary institution in the Niger Delta. Int JMed Biomed Res 2013;2(1):48-56.

[41]. Parham, G.P, sahasarabuddhe V.V and Mwanshamuntu, M.H. (2004). Prevalence and predictors of squamous intraepithelial lesions of the cervix in HIV infected women, published by CIDRZ, Lusaka.

[42]. Parkin D.M., Ferlay J., Hamdi-Cherif M., Sitas F., Thomas J.O., Wabinga H. Whelanet SL. (2003): Cancer in Africa: Epidemiology and Prevention. Cervix Cancer. Scientific Publications IARC, Lyon.153, 268276.

[43]. Peto J, Gilham C, Fletcher O, Matthews FE. The cervical cancer epidemic that screening has prevented in the UK. Lancet 2004; 364:249- 256.

[44]. Quinn M, Babb P, Jones J, Allen E. Effect of screening on incidence of and mortality from cancer of cervix in England: evaluation based on routinely collected statistics. BMJ 1999; 318:904- 908.

[45]. SA Olowookere, EA Abioye - Kuteyi, EP, Airewele. Awareness and uptake of Human papilloma virus vaccination and cervical screening among female undergraduate students in a tertiary institution in Nigeria Journal of family Practice, Vol3, Nol (2012).

[46]. Sherifa E.W. Puteh, Paul NG, and Syed M Aljumid. Economic burden of cervical cancer in Malaysia, Medical Journal of Indonesia, Vol17, No4 (2008)

[47]. WHO (2002) Cervical cancer screening in developing countries report of a WHO consultation. Genera world health organization. Accessed on the $16^{\text {th }}$ of January, 2016.

[48]. WHO (2007a) WHO web site http://who.int/mediacentre. Accessed on the $16^{\text {th }}$ of January, 2016.

[49]. WHO (2007b) WHO calls for prevention of cancer through healthy workplaces. http:// www.who.int/mediacentre/news/notes/2007/np/index.html. Accessed on the $16^{\text {th }}$ of January, 2016.

[50]. World Health Organisation. (2002). Control of cancer of the cervix uteri; international Journal of cancer, Geneva. Accessed on the $16^{\text {th }}$ of January, 2016. 